|Araştırma Makalesi / Research Article |

\title{
2005 ve 2018 Sosyal Bilgiler Ders Kitaplarındaki Derse Özgü Becerilerin Öğretiminin Karşılaştırılması
}

\section{Comparison of Teaching of Course Specific Skills in 2005 and 2018 Social Studies Course Books}

\section{Gülşah Kuru' ${ }^{1}$ Ahmet Şimşek²}

Anahtar Kelimeler

1.Sosyal Bilgiler Ders

Kitab

2. Sosyal Bilgiler Öğretim

Programı

3.Temel Beceriler

4.Beceri Eğitimi

5.Sınıf Öğretmeni

Keywords
1. Social Studies
Textbook,
2. Social Studies
Curriculum
3. Basic Skills
4.Teaching Skills
5.Primary School
Teacher

Teacher

Başvuru Tarihi/Received

11.03.2020

Kabul Tarihi /Accepted

29.11.2020

Öz

Beceri kavramı; öğrencilerde, öğrenme süreci içerisinde kazanılması, geliştirilmesi ve yaşama aktarılması tasarlanan kabiliyetler olarak tanımlanmaktadır. Yaşamın karmaşıklaşması, eğitilmiş insan sayısının çoğalması, günün koşullarına etkin bir şekilde uyum sağlayabilme, iletişimin artıp bilgi kaynaklarının çeşitlenmesi gibi sebeplerle eğitim ve öğretim sürecinde beceri kazandırmanın önemli olduğu düşünülmektedir. Bu araştırmada, 2005 ve 2018 Sosyal Bilgiler ders kitaplarında derse özgü becerilerin öğretimi karşılaştırılarak incelenmiştir. Araştırmada, nitel araştırma yöntemlerinden doküman incelemesi kullanılmışır. Araştırma verilerini, 2005 ve 2018 Sosyal Bilgiler öğretim programları ile ders kitapları oluşturmaktadır. Verilerin analizinde, betimsel analizden yararlanılmıştır. Araştırma sonucunda; 2018 yılında, 2005'e göre, daha fazla becerinin farklı metin türleriyle öğrencilere kazandııılmaya çalışıldığı görülmektedir. Ders kitaplarındaki görseller incelendiğinde; 2005'de derse özgü beceriler için kullanılan görsellerde kavram karikatürlerinden yararlanıldı̆̆ı, 2018' de kavram karikatürlerinin bulunmadığı, 2005 ders kitabında daha fazla görsel, daha az yazı kullanılıp bu durumun 2018'de tersi olduğu görülmüştür. Ölçme ve değerlendirme boyutunda incelendiğindeyse; açık uçlu sorular kullanıldı̆̆ı, 2018'de sorular aracılığıyla daha çok becerinin kazandırılmaya çalışıldı̆̆ı; ancak değerlendirilme boyutunun yeterli olmadığı sonucuna ulaşılmıştır.

\section{Abstract}

The concept of skill; it is defined as the abilities designed to be acquired, developed and put into life in students during the learning process. It is thought that it is important to gain skills in the education and training process due to the complications of life, the increase of the number of trained people, the ability to adapt to the conditions of the day effectively, the increase in communication and the diversification of information resources. In this research, teaching of lesson-specific skills in 2005 and 2018 Social Studies textbooks was compared and analyzed. In the research, document review, one of qualitative research methods, was used. Research data consists of 2005 and 2018 Social Studies curricula published by Ministry of National Education and textbooks prepared for these programs. Descriptive analysis was used in analysis of data. In the research; in 2018 textbook, it is seen more skills are tried to be acquired by students with various text types. When visuals in textbooks are examined; it was determined concept cartoons were frequently used in visuals used for course-specific skills in 2005, there were no concept cartoons in 2018 and more visuals, less writing were used in 2005 textbook, this was the opposite in 2018. The visuals used in 2005 textbook are more realistic. In terms of measurement and evaluation; questions are generally openended; in 2018, more skills were tried to be gained through questions; it was concluded that it was not sufficient to acquire course-specific skills in assessment and evaluation section.

\footnotetext{
${ }^{1}$ Sorumlu Yazar, İstanbul Üniversitesi-Cerrahpaşa, Lisansüstü Eğitim Enstitüsü, Sınıf Eğitimi A.B.D., İstanbul, TÜRKiYE; https://orcid.org/0000-0003-2428-9972 2 İstanbul Üniversitesi-Cerrahpaşa, Hasan Ali Yücel Eğitim Fakültesi, Sınıf Eğitimi A.B.D., İstanbul, TÜRKiYE; https://orcid.org/0000-0003-3591-8180
} 


\section{Introduction}

Social Studies is a discipline that aims to raise citizens who think, become active and skilled with democratic values in a globalizing world. It is seen that the studies related to the Social Studies course in our country are carried out on the basis of the curriculum. When the development process of Social Studies from past to present is analyzed, it is the first time that it was included in the 1968 program under this name; 1924, 1926, 1936, 1948, 1968, 1998, 2005, 2015, 2017, by changing the curriculum, it is seen that the final form of the program was given in 2018. It is noteworthy that the most radical changes made when comparing the Social Studies curriculum are in the program in 2005 . When the Social Studies curriculum is examined, it is known that the gains are mostly "knowledge"oriented; however, it is observed that with the changes in 2005 and afterwards, it is given importance to gain "skill" in Social Studies curriculum. The concept of skill; it is defined as the abilities designed to be acquired, developed and put into life in students during the learning process. In the 2005 Social Studies curriculum; critical thinking, creative thinking, communication, research, problem solving, decision making, using information technologies, entrepreneurship, using Turkish correctly, beautifully and effectively, observation, perception of space, perception of time and chronology, perception of change and continuity, social participation and empathy skills There are 15 skills (Kıroğlu, 2006; MEB, 2005; Sözen \& Ada, 2018) in the program, 6 of these skills (observation, perception of space, perception of time and chronology, perception of change and continuity, social participation and empathy) it is stated that there are skills specific to the course (MEB, 2005); in the 2018 Social Studies curriculum; in addition to the skills included in the 2005 program; digital literacy, financial literacy, recognizing stereotypes and prejudices, location analysis, media literacy, drawing and interpreting tables, graphics and diagrams, innovative thinking, collaboration, environmental literacy, perceiving change and continuity, map and legal literacy, using evidence, decision There were 27 skills in total, namely giving, self-control and political literacy (MEB, 2018; Sözen \& Ada, 2018). As in the 2005 program, observation, perception of space, perception of time and chronology, perception of change and continuity, social participation and empathy skills, as well as map literacy, stereotype and prejudice, using evidence, location analysis, media literacy and political literacy. 12 skills were accepted as course-specific skills. In this study, it is aimed to compare teaching of lesson-specific skills in 2005 and 2018 Social Studies textbooks. For this purpose: What are the lesson-specific skills that are aimed to be brought directly to the students according to their learning areas in the 2005 and 2018 Social Studies curriculum. How were these skills handled in the texts, visuals and assessment process in the 2005 and 2018 Social Studies textbooks? Answers to the questions were sought.

\section{Method}

In this research, document review method, one of the qualitative research methods, was used. The sample of the research consists of 2005 and 2018 Social Studies curricula with the decision of the Ministry of National Education Board of Education and Discipline and 4th grade textbooks prepared according to these programs. Research data was analyzed by descriptive analysis and evaluation was made based on 3 criteria determined by the researcher. These criteria are given below.

1. Handling skills in textbooks,

2. Handling skills in visuals in textbooks,

3. The handling of skills in terms of measurement and evaluation dimension in textbooks.

\section{Result and Discussion}

As a result of the research; in the 2018 textbook, it is seen that more skills are tried to be acquired by students with various text types compared to 2005. When the visuals in the textbooks are examined; it was determined that concept cartoons were frequently used in the visuals used for course-specific skills in 2005, there were no concept cartoons in 2018, and more visuals, less writing were used in the 2005 textbook, and this was the opposite in 2018. The visuals used in the 2005 textbook are more realistic. When the textbooks are analyzed in terms of measurement and evaluation; the questions prepared are generally open-ended; in 2018, more skills were tried to be gained through questions; however, according to the texts used and the visuals used, it was concluded that it was not sufficient to acquire course-specific skills in the assessment and evaluation section. For the measurement and evaluation in the textbooks; instead of asking students $5 \mathrm{~N} 1 \mathrm{~K}$ questions with short answers, in accordance with the requirement of the 21st century; It is believed that it is important to use open-ended questions that lead to higher-level thinking in terms of raising individuals who think, research and question. It is recommended that the textbooks are prepared in this direction and that qualified questions in the measurement-evaluation dimension are included. It may be suggested to review the existing questions and to prepare qualified questions by reviewing them in terms of being open-ended but appropriate for student level. 
Sosyal Bilgiler, küreselleşen bir dünyada demokratik değerlerle donatılan, düşünen, etkin ve beceri sahibi vatandaşlar yetiştirmeyi amaçlayan bir disiplindir. Ülkemizde Sosyal Bilgiler dersine ilişkin çalışmaların, öğretim programı temelinde yapıldığı görülmektedir. Siyasi, ekonomik, toplumsal ve kültürel alandaki gelişmeler ve bilimin, teknolojinin hızla gelişmesi; bu gelişmelerin eğitime yansımasını ve öğretim programlarının da değişen koşullara uygun hale getirilmesini zorunlu kılmaktadır (Tay, 2017). ilkkokulda Sosyal Bilgiler, öğrencilerin öğrendiklerini günlük yaşamlarında uygulayabilmeleri için, öğrenme alanlarının farklı teori ve ilkeler kullanılarak bütünleştirilmesi gereken disiplinlerarası bir konudur (Chuang, Hwang ve Tsai, 2018). Türkiye'de Sosyal Bilgiler dersinin geçmişten günümüze gelişim süreci incelendiğinde; dersin bu adla ilk kez 1968 programında yer aldığl; 1924, 1926, 1936, 1948, 1968, 1998, 2005, 2015, 2017 yılları öğretim programlarında da değişikliğe uğrayarak, programa son şeklinin 2018'de verildiği görülmektedir (Kaymakcı, 2009; Milli Eğitim Bakanlı̆̆ı [MEB], 2005).

Sosyal Bilgiler öğretim programları karşılaştırıldığında yapılan en köklü değişikliklerin 2005 yılındaki programda olduğu dikkat çekmektedir. 2005 Sosyal Bilgiler öğretim programı, sosyal oluşturmacılı̆̆ benimsemiş, bu doğrultuda dersin temeli "tematik" anlayışa dayanmıştır. 2005 programı, önceki programlardan ayrılan ve sonraki programlara ışık tutan birçok farklılıktan oluşmuştur. Ders kitaplarının öğretmen kılavuz kitabı, ders kitabı ve öğrenci çalışma kitabı olmak üzere bir setten oluşması, disiplinler arası bir yaklaşım doğrultusunda hareket etmesi, hedef ve davranış ifadelerinin yerine "kazanım" ifadesinin kullanılması, davranış̧ı yaklaşımın yerini 'yapılandırmacı' yaklaşımın alması, öğrenme alanı, beceri, değer, ilişkilendirme, ara disiplinler ve yapılandırmacı değerlendirmenin olması bu farklılıklara örnek olarak verilebilir (Kıroğlu, 2006; Tay, 2017). Temelinin 2005 programında atıldığı, şuan uygulamada olan Sosyal Bilgiler öğretim programı da salt bilgi aktarmaktan ziyade; öğrencilerin bireysel farklılıklarını dikkate alan, sade, anlaşılır, "değer” ve "beceri” kazandırmayı hedefleyen bir yapıdadır (Milli Eğitim Bakanlığı, 2018; Yalçın ve Akhan, 2019).

Beceri kavramı; öğrencilerde, öğrenme süreci içerisinde kazanılması, geliştirilmesi ve yaşama aktarılması tasarlanan kabiliyetler olarak tanımlanmaktadır (Milli Eğitim Bakanlığı, 2005; MEB, 2018).Yaşamın karmaşıklaşması, eğitilmiş insan sayısının çoğalması, günün koşullarına etkin bir şekilde uyum sağlayabilme, iletişimin artıp bilgi kaynaklarının çeşitlenmesi gibi sebeplerle eğitim ve öğretim sürecinde beceri kazandırmanın önemli olduğu düşünülmektedir (Mutluer, 2013).

2005 Sosyal Bilgiler öğretim programında; eleştirel düşünme, yaratıcı düşünme, iletişim, araştırma, problem çözme, karar verme, bilgi teknolojilerini kullanma, girişimcilik, Türkçeyi doğru, güzel ve etkili kullanma, gözlem, mekânı algılama, zaman ve kronolojiyi algılama, değişim ve sürekliliği algılama, sosyal katılım ve empati becerisi olmak üzere 15 beceri yer almakta olup (Kıroğlu, 2006; MEB, 2005; Sözen ve Ada, 2018) programda bu becerilerin 6'sının (gözlem, mekânı algılama, zaman ve kronolojiyi algılama, değişim ve sürekliliği algılama, sosyal katılım ve empati becerisi) derse özgü beceriler olduğu belirtilmiş (MEB, 2005); 2018 Sosyal Bilgiler öğretim programında ise; 2005 programında yer alan becerilere ek olarak; dijital okuryazarlık, finansal okuryazarlık, kalıp yargı ve önyargıyı fark etme, konum analizi, medya okuryazarlığı, tablo, grafik ve diyagram çizme ve yorumlama, yenilikçi düşünme, işbirliği, çevre okuryazarlığı, değişim ve sürekliliği algılama, harita ve hukuk okuryazarlığı, kanıt kullanma, karar verme, özdenetim ve politik okuryazarlık olmak üzere toplam 27 beceri yer almıştır (MEB, 2018; Sözen ve Ada, 2018). 2005 programında olduğu gibi, gözlem, mekânı algılama, zaman ve kronolojiyi algılama, değişim ve sürekliliği algılama, sosyal katılım ve empati becerileri ile bunlara ek olarak harita okuryazarlığı, kalıp yargı ve önyargıyı fark etme, kanıt kullanma, konum analizi, medya okuryazarlığı ve politik okuryazarlık olmak üzere 12 beceri derse özgü beceriler olarak kabul edilmiştir (MEB, 2018).

Literatür incelendiğinde; Sosyal Bilgiler öğretim programlarında yer alan becerilerin öğrencilere kazandırılması ile ilgili yapılan araştırmalarda daha çok, öğretmen görüşleri alındığı ve araştırma sonuçlarında bu becerilerin öğrencilere yeterli düzeyde kazandırılamadığı, öğretmenlerin müfredatta yer alan beceriler ve bu becerilerin öğretimi konusunda yeterince bilgi sahibi olmadığı ve becerilerin kazandırılmasında ders kitaplarını da yeterli bulmadıkları görülmektedir (Çelikkaya, 2011; Hayırsever ve Kısakürek, 2014; Mutluer, 2013; Öztürk ve Mutlu; 2017).

Beceri öğretiminde ders kitapları üzerine yapılan çalışmalar incelendiğinde ise; beceri ve beceri eğitimine ilişkin bilgilere öğretmen kılavuz kitaplarında 4.sınıfta yer verilmediği; mekânı algılama ile tablo, diyagram ve grafik okuma becerilerinin bu sınıf düzeyinde en fazla üzerinde durulan beceriler olduğu ve Sosyal Bilgiler dersine ait alan becerilerinden mekânı algılama, gözlem ve tarihsel olguları ve yorumları ayırt etme becerilerinin öğrencilere iyi şekilde aktarılırken, tablo, diyagram ve grafik okuma, sosyal katılım ve grafik hazırlama becerilerinin ise yeterli düzeyde aktarılamadığı (Çelikkaya ve Kürümlüoğlu, 2019) ve ders kitaplarında becerilerin tüm etkinlikler içerisinde dengeli bir dağılım göstermeyip ortak becerilere daha fazla yer verildiği, derse özgü becerilere ise daha yer az yer verildiği (Aydemir ve Adamaz, 2017) sonuçlarına ulaşılmaktadır.

Sosyal Bilgiler öğretim programında yer alan beceriler, 21.yy’ın gereğine uygun şekilde öğrenci yetiştirilmesini hedefleyen becerilerdir. Bu ders aracılığıyla, öğrencilerin temel becerileri öğrenme sürecinde kazanmaları ve bu becerileri yaşamlarına en iyi şekilde aktarabilmeleri amaçlanmaktadır. Çağın koşulları göz önüne alındığında eğitim sistemleri; araştıran, düşünen, sorgulayan bireyler yetiştirilmesini zorunlu kılmaktadır. Bu sebeple, bireylerin Sosyal Bilgiler öğretim programında belirtilen temel becerileri ve Sosyal Bilgiler dersine ait becerileri kazanması önem arz etmektedir (Çelikkaya, 2011). Ders kitaplarının ise, öğrencilerin öğrenme düzeyini etkileyen faktörlerden biri olduğu (Önal ve Kaya, 2006) ve eğitim kurumlarında sıklıkla kullanıldığı göz önüne alındığında; beceri öğretiminin kazandırımaya çalışmasında ders kitaplarının önemli bir araç olduğu düşünülmektedir. Literatür incelendiğinde, bu konuda yapılan çalışmaların yeterli sayıda olmadığı, yapılan çalışmaların genellikle öğretmen görüşleriyle sınırlı kaldığı; ders kitabı incelemeye yönelik çalışmaların ise daha çok, Sosyal Bilgiler dersi öğretim programında yer alan değerlere 
yönelik olduğu görülmektedir (Cüro ve Gömleksiz, 2011; Kuş, Merey ve Karatekin, 2013). İçinde bulunduğumuz çağda, beceri eğitiminin sıklıkla vurgulanıp, yeni öğretim programlarında beceri eğitimi üzerinde önemle durulduğu görülmektedir. Bu sebeple, okullarda kullanılan, temel eğitim araç gereçlerinden biri olan ders kitaplarının beceri eğitimi boyutunda ele alınmasının önem arz ettiği düşünülmektedir. İlgili literatür incelendiğinde, konu ile ilgili yapılan çalışmaların yeterli sayıda olmadığı görülmekte olup araştırmanın alana katkı sağlayacağı düşünülmektedir. Bu araştırmada, 2005 ve 2018 Sosyal Bilgiler ders kitaplarında, derse özgü becerilerin öğretiminin karşılaştırılması amaçlanmaktadır. Bu amaçla aşağıdaki sorulara yanıt aranmıştır:

1. 2005 ve 2018 Sosyal Bilgiler öğretim programlarında öğrenme alanlarına göre öğrencilere doğrudan kazandırılması hedeflenen derse özgü beceriler nelerdir?

2. 2005 ve 2018 Sosyal Bilgiler ders kitaplarında yer alan metinlerde, programda belirtilen derse özgü beceriler nasıl ele alınmıştır?

3. 2005 ve 2018 Sosyal Bilgiler ders kitaplarında yer alan görsellerde programda belirtilen derse özgü beceriler nasıl ele alınmıştır?

4. Öğrenme alanlarına göre sınıflandırıldığında 2005 ve 2018 Sosyal Bilgiler ders kitaplarındaki ölçme ve değerlendirme boyutunda derse özgü beceriler nasıl ele alınmıştır?

\section{YÖNTEM}

\section{Araştırmanın Modeli}

Talim ve Terbiye Kurulu kararıyla onaylanan 2005 ve 2018 Sosyal Bilgiler ders kitaplarında yer alan metinleri, görselleri ve soruları; dersin öğretim programlarındaki ortak ve derse özgü beceriler açısından incelemek amacıyla bu araştırmada nitel araştırma yöntemlerinden doküman incelemesi yöntemi kullanılmıştır. Doküman incelemesinde; araştırılması hedeflenen olgu veya olaylar hakkında bilgi içeren yazılı materyallerin analiz edilmesi amaçlanmaktadır (Yıldırım ve Şimşek, 2013).

\section{Çalışma Grubu}

Araştırmanın örneklemini, Millî Eğitim Bakanlığı Talim ve Terbiye Kurulu kararıyla 2005 ve 2018 yılı Sosyal Bilgiler öğretim programları ve bu programlara göre hazırlanmış ilköğretim 4.sınıf ders kitapları oluşturmaktadır. Araştırmada; 4.sınıf Gizem Yayıncılık Milli Eğitim Bakanlığı Talim ve Terbiye Kurulu Başkanlığı'nın 18.07.2005 tarih ve 255 sayılı Kurul Kararı ve 4.sınıf Tuna Yayınevi Milli Eğitim Bakanlığı Talim ve Terbiye Kurulu Başkanlığı'nın 28 Mayıs 2018 tarih ve 78 sayılı kararıyla (listenin 25.sırasında) kabul edilen Sosyal Bilgiler ders kitapları kullanılmıştır.

\section{Veri Toplama Araçları ve Verilerin Analizi}

Araştırmada incelenmiş olan 2018 öğretim programına, Milli Eğitim Bakanlığı́nın internet sitesinden PDF olarak; 2005 programına ve 2005 ile 2018 ders kitaplarına ise, basılı materyal olarak ulaşılmıştır.

Araştırmada öncelikli olarak, 2005 Sosyal Bilgiler dersi öğretim programında belirtilen derse özgü beceriler (gözlem, mekânı algılama, zaman ve kronolojiyi algılama, değişim ve sürekliliği algılama, sosyal katılım ve empati becerisi) ve 2018 Sosyal Bilgiler dersi öğretim programında yer alan derse özgü beceriler (değişim ve sürekliliği algılama, eleştirel düşünme, empati, harita okuryazarlığı, kalıp yargı ve önyargıyı fark etme, kanıt kullanma, konum analizi, medya okuryazarlığı, mekanı algılama, politik okuryazarlık, sosyal katılım ve zaman ve kronolojiyi algılama) belirlenmiş, sonrasında bu becerilerin ders kitaplarında yer alma durumları tespit edilip karşılaştırılmaya çalışılmıştır. Araştırma verileri, betimsel analiz ile çözümlenmiştir. Betimsel analiz; verilerin gösterildiği, betimlendiği, anlatıldığı bir irdeleme, bir olayın neden oluştuğu ve kimleri ilgilendirdiği sorularına cevap vermek üzere elde edilmiş verilerin daha önceden belirlenmiş temalara göre özetlenmesi ve yorumlanmasını içeren nitel veri analiz türüdür (Yıldırım ve Şimşek, 2013). Betimsel analiz, dört aşamada gerçekleşmektedir. Birinci aşamada araştırmacı araştırma sorularından, araştırmanın kavramsal çerçevesinden, alan yazın taramalarından elde ettiği boyutlar ile veri analizi için bir çerçeve oluşturur. Bu, verilerin hangi temalar altında düzenleneceği ve sunulacağının belirlenmesini sağlar. Araştırmacı daha önce oluşturmuş olduğu çerçeveye dayalı olarak verileri okur, düzenler ve sayısallaştırır (Dawson, 2009). Bu araştırmada, araştırmacı tarafından belirlenen 3 ölçüt üzerinden değerlendirme yapılmıştır. Bu ölçütler aşağıda verilmiştir.

Ders kitaplarındaki metinlerde becerilerin ele alınışı, ders kitaplarındaki görsellerde becerilerin ele alınışı ve ders kitaplarında yer alan ölçme ve değerlendirme boyutu açısından becerilerin ele alınışı. Belirlenmiş bu ölçütler doğrultusunda ders kitapları incelenerek elde edilen veriler betimsel analiz yöntemi kullanılarak çözümlenmiştir.

\section{Geçerlik ve Güvenirlik}

Araştırmada elde edilen verilerin analizinde, iki araştırmacı yer almış; araştırmanın analizi, araştırmacılar tarafından eş zamanlı olarak birbirinden bağımsız yapılıp ortaya çıkan kategori ve kodlar karşılaştırılmış ve fikir birliğine varılmıştır. Çalışmanın güvenirlik hesaplaması için Miles ve Huberman'a (1994) ait güvenirlik hesaplama formülünden yararlanılıp analiz sonuçları sayısallaştırılarak \%88'lik uyum sonucu ile çalışma güvenilir kabul edilmiştir. Süreç boyunca uzman görüşlerine başvurulmuştur. 


\section{BULGULAR VE TARTIŞMA}

Bu bölümde, 2005 ve 2018 Sosyal Bilgiler ders kitaplarındaki derse özgü becerilerin öğretiminin karşılaştırılmasına yönelik bulgulara yer verilmiştir.

\section{5 ve 2018 Sosyal Bilgiler Dersi Öğretim Programlarında Yer Alan Derse Özgü Beceriler ve Öğrenme Alanları}

Öğretim programlarında yer alan öğrenme alanı-derse özgü beceri eşleştirmesi Tablo 1.'de verilmiştir.

Tablo 1. Öğrenme alanlarına göre doğrudan verilmesi beklenen becerilerin dağılımı

\begin{tabular}{|c|c|c|}
\hline $\begin{array}{l}\text { Öğretim } \\
\text { Programları }\end{array}$ & Öğrenme Alanları & Doğrudan Verilmesi Beklenen Becerilerin Dağılımı \\
\hline 2005 Programı & $\begin{array}{l}\text { 1.Birey ve Toplum } \\
\text { 2.Kültür ve Miras } \\
\text { 3.Insanlar, Yerler ve Çevreler } \\
\text { 4.Üretim, Dağıtım ve Tüketim } \\
\text { 5.Bilim Teknoloji ve Toplum } \\
\text { 6.Gruplar, Kurumlar ve Sosyal 7.Örgütler } \\
\text { 8.Güç, Yönetim ve Toplum } \\
\text { 9.Küresel Bağlantılar }\end{array}$ & $\begin{array}{l}\text { 1.Kanıt Kullanma } \\
\text { 2.Araştırma } \\
\text { 3.Mekânı Algılama } \\
\text { 4.Mekânı Algılama } \\
\text { 5.Eleştirel Düşünme } \\
\text { 6.Eleştirel Düşünme } \\
\text { 7.Karar Verme } \\
\text { 8.Araştırma } \\
\text { 9.Araştırma }\end{array}$ \\
\hline 2018 Programı & $\begin{array}{l}\text { 1.Birey ve Toplum } \\
\text { 2.Kültür ve Miras } \\
\text { 3.Insanlar, Yerler ve Çevreler } \\
\text { 4.Bilim Teknoloji ve Toplum } \\
\text { 5.Üretim, Dağıtım ve Tüketim } \\
\text { 6.Etkin Vatandaşlık } \\
\text { 7.Küresel Bağlantılar }\end{array}$ & $\begin{array}{l}\text { 1.Kanıt Kullanma, Zaman ve Kronolojiyi Algılama ile } \\
\text { Empati kurma } \\
\text { 2.Kanıt Kullanma, Zaman ve Kronolojiyi Algılama ile } \\
\text { Değişim ve Sürekliliği Algılama } \\
\text { 3.Mekânı Algılama, Harita Kullanma, Konum Analizi, } \\
\text { Tablo, Grafik, Diyagram Çizme ve Yorumlama } \\
\text { 4.Değişim ve Sürekliliği Algılama } \\
\text { Öz Denetim, Karar Verme ve Finansal Okuryazarlık } \\
\text { 5.İ̧̧ Birliği, Sosyal Katılım ve Karar Verme } \\
\text { 6.Araştırma ve Empati } \\
\text { 7.Araştırma ve Empati }\end{array}$ \\
\hline
\end{tabular}

(Kaynak: MEB 2005, 2018)

2018 programında bir öğrenme alanı ile doğrudan verilmesi beklenen birden fazla becerinin olduğu, 2005 programında ise, her öğrenme alanının bir beceriyle eşleştirilip aynı becerilerin tekrar ettiği görülmektedir. Bu durum, yeni programda beceri eğitimine daha fazla önem verildiğinin bir göstergesi olarak kabul edilebilir. Bir öğrenme alanı ile birden fazla becerinin kazandırılmaya çalışıımasının ise, beceriler arası ilişki kurularak kazanılması beklenen becerileri pekiştirme amacı taşıdığı söylenebilir.

\section{Öğrenme Alanlarına Göre 2005 ve 2018 Ders Kitaplarında Sosyal Bilgiler Dersine Özgü Becerilerin Ele Alınışı}

Bu bölümde derse özgü becerilerin ele alınışı, ilgili ders kitapları incelenerek; program ve bu programlarda yer alan öğrenme alanlarına göre sınıflandırılıp; metin türü, görsellerin kullanımı ve kitapta yer alan değerlendirme boyutu açısından incelenmiştir.

\section{Metinlerde Derse Özgü Becerilerin Ele Alınışı}

Tablo 2'de 2005 ve 2018 öğretim programlarında “aynı adı taşıyan” öğrenme alanlarındaki derse özgü becerilerin; Tablo 3’te ise, "farklı adı taşıyan” öğrenme alanlarındaki derse özgü becerilerin metin türleri açısından ele alınışı yer almaktadır.

Tablo 2. Her iki programda yer alan öğrenme alanlarındaki derse özgü becerilerin metin türlerine göre ele alınışı

\begin{tabular}{|c|c|c|c|}
\hline Öğrenme Alanları & Öğretim Programları & Ele Alınan Beceriler & Metin Türü \\
\hline \multirow{2}{*}{ Birey ve Toplum } & 2005 Programı & -Empati & -Bilgilendirici kısa metinler \\
\hline & 2018 Programı & $\begin{array}{c}\text {-Kanıt Kullanma } \\
\text {-Zaman ve Kronolojiyi Algılama ile } \\
\text { Değişim ve Sürekliliği Algılama } \\
\text {-Empati }\end{array}$ & $\begin{array}{l}\text {-Bilgilendirici uzun metinler } \\
\text {-Biyografi ile örnek olay } \\
\text { metinleri } \\
\text {-Röportaj, düz metin ve şiir }\end{array}$ \\
\hline \multirow[b]{2}{*}{ Kültür ve Miras } & 2005 Programı & $\begin{array}{c}\text {-Zaman ve Kronolojiyi Algılama ile } \\
\text { Değişim ve Sürekliliği Algılama }\end{array}$ & -Şiir, röportaj ve tiyatro metni \\
\hline & 2018 Programı & $\begin{array}{c}\text {-Kanıt Kullanma } \\
\text {-Zaman ve Kronolojiyi Algılama ile } \\
\text { Değişim ve Sürekliliği Algılama } \\
\text {-Politik Okuryazarlık }\end{array}$ & $\begin{array}{l}\text {-Bilgilendirici uzun metinler } \\
\text {-Biyografi, anı ve örnek olay } \\
\text { metni } \\
\text {-Bilgilendirici uzun metin }\end{array}$ \\
\hline
\end{tabular}




\begin{tabular}{|c|c|c|c|}
\hline Öğrenme Alanları & Öğretim Programları & Ele Alınan Beceriler & Metin Türü \\
\hline \multirow{2}{*}{$\begin{array}{l}\text { İnsanlar, Yerler ve } \\
\text { Çevreler }\end{array}$} & 2005 Programı & $\begin{array}{c}\text {-Mekânı Algılama } \\
\text {-Empati }\end{array}$ & $\begin{array}{c}\text {-Anı, Mektup } \\
\text {-Şiir ve bilgilendirici uzun } \\
\text { metinler }\end{array}$ \\
\hline & 2018 Programı & $\begin{array}{c}\text {-Mekânı Algılama } \\
\text {-Harita Okuryazarlığı ile Konum } \\
\text { Analizi } \\
\text {-Empati }\end{array}$ & $\begin{array}{c}\text {-Bilgilendirici kısa metinler } \\
\text {-Bilgilendirici uzun metinler } \\
\text {-Tiyatro }\end{array}$ \\
\hline \multirow[b]{2}{*}{$\begin{array}{l}\text { Üretim, Tüketim ve } \\
\text { Dağıtım }\end{array}$} & 2005 Programı & -Gözlem ve Mekânı Algılama & $\begin{array}{c}\text {-Gazete haberleri, fıkra, şiir, } \\
\text { karikatür }\end{array}$ \\
\hline & 2018 Programı & $\begin{array}{l}\text {-Gözlem ve Mekânı Algılama } \\
\text {-Değişim ve Sürekliliği Algılama ile } \\
\text { Zaman ve Kronolojiyi Algılama }\end{array}$ & $\begin{array}{l}\text {-Bilgilendirici uzun metinler, } \\
\text { bilgilendirici kısa metinler } \\
\text {-Bilgilendirici kısa metinler, } \\
\text { bilgilendirici uzun metinler, } \\
\text { şiir }\end{array}$ \\
\hline \multirow{2}{*}{ Bilim Teknoloji ve Toplum } & 2005 Programı & $\begin{array}{l}\text {-Değişim ve Sürekliliği Algılama ile } \\
\text { Zaman ve Kronolojiyi Algılama }\end{array}$ & $\begin{array}{l}\text {-Kavram karikatürleri, } \\
\text { bilgilendirici kısa metinler, } \\
\text { günlük, gazete haberleri }\end{array}$ \\
\hline & 2018 Programı & $\begin{array}{c}\text { - Değişim ve Sürekliliği Algılama, } \\
\text { Zaman ve Kronolojiyi Algılama ve } \\
\text { Mekânı Algılama }\end{array}$ & -Bilgilendirici metinler \\
\hline \multirow[b]{2}{*}{ Küresel Bağlantılar } & 2005 Programı & -Sosyal Katılım & $\begin{array}{c}\text {-Gazete haberleri, } \\
\text { bilgilendirici kısa metinler, şiir }\end{array}$ \\
\hline & 2018 Programı & $\begin{array}{c}\text {-Empati, Sosyal Katılım ve Politik } \\
\text { Okuryazarlık }\end{array}$ & $\begin{array}{l}\text {-Bilgilendirici metinler, } \\
\text { dilekçe, gazete haberleri }\end{array}$ \\
\hline
\end{tabular}

2018 ders kitabında, öğrenme alanlarının her biri için daha fazla becerinin öğrencilere kazandırılmaya çalışıldığı, metin türleri açısından incelendiğinde; 2018 ders kitabındaki bilgilendirici metinlerin 2005 ders kitabına göre daha uzun olduğu ve 2018 ders kitaplarındaki metin türlerinin beceri kazandırılma açısından 2005'e göre daha fazla çeşitlilik gösterdiği görülmektedir.

Tablo 3. Programlarda ortak olmayan öğrenme alanlarındaki derse özgü becerilerin metin türlerine göre ele alınışı

\begin{tabular}{lccc}
\hline $\begin{array}{l}\text { Öğretim } \\
\text { Programları }\end{array}$ & Öğrenme Alanları & Ele Alınan Beceriler & Metin Türü \\
\hline 2005 Programı & $\begin{array}{c}\text { Gruplar, Kurumlar ve } \\
\text { Sosyal Örgütler }\end{array}$ & -Sosyal Katılım ve Empati & $\begin{array}{c}\text {-Gazete haberleri, mektup, dilekçe, fıkra, } \\
\text { röportaj, şiir, bilgilendirici kısa metin }\end{array}$ \\
\hline 2005 Programı & $\begin{array}{c}\text { Güç, Yönetim ve } \\
\text { Toplum }\end{array}$ & $\begin{array}{c}\text {-Sosyal Katılım } \\
\text {-Empati }\end{array}$ & -Gazete haberleri, örnek olay, dilekçe \\
\cline { 3 - 4 } 2018 Programı & Etkin Vatandaşlık & $\begin{array}{c}\text {-Sosyal Katılım, Empati, } \\
\text { Politik Okuryazarlık }\end{array}$ & -Bilgilendirici metinler, anı \\
\hline
\end{tabular}

Programlardaki ortak olmayan öğrenme alanlarına göre becerilerin nasıl ele alındığı incelendiğinde, sosyal katılım ve empati becerileri üzerinde durulduğu görülmektedir. Sosyal katılım ve empati becerilerinin öğrencilere kazandırılması açısından, 2005 ders kitabının 2018'e göre metin türü bakımından çeşitlilik gösterdiği göze çarpmaktadır.

Literatür incelendiğinde; kanıt kullanma becerisinin üzerinde daha çok 2018 programında durulup bilgilendirici uzun metinler aracılığıyla bu becerinin öğrencilere kazandırılmaya çalışıldığı görülmektedir. Bu araştırmanın bulgularından yola çıkarak, zaman ve kronolojiyi algılama ile değişim ve sürekliliği algılama becerilerinin her iki ders kitabında da üzerinde sıklıkla durulan beceriler olduğu, bu becerilerin 2018 ders kitabında biyografi ve örnek olay metinleri gibi gerçek hayat durumlarına uygun metinler aracılığıyla öğrencilere kazandırılması hedeflenirken; 2005'te kavram karikatürleri, şiir, röportaj, tiyatro gibi eğlenceli metinler aracılığıyla öğrencilere kazandırılmaya çalışıldığı görülmüştür.

Kaymakcı (2013), araştırmasında; Sosyal Bilgiler 4. sınıf ders kitaplarında sıklıkla hikâye, anı ve biyografi gibi gerçek hayat durumlarından yararlanıldığı, en az oranda ise; tiyatro ve mektup türlerinden yararlanıldığı sonucuna ulaşmıştır. Araştırma sonuçlarının benzerlik gösterdiği görülmektedir. Programlardaki ortak olmayan öğrenme alanlarına göre (Gruplar, Kurumlar ve Sosyal Örgütler, Güç, Yönetim ve Toplum ve Etkin Vatandaşlık) becerilerin nasıl ele alındığı incelendiğinde, sosyal katılım ve empati becerileri üzerinde durulduğu görülmektedir. Literatür de bunu destekler niteliktedir (Karasu-Avcı ve Faiz, 2018). Sosyal katılım ve empati becerilerinin öğrencilere kazandırılması açısından, 2005 ders kitabının 2018'e göre metin türü bakımından çeşitlilik gösterdiği göze çarpmaktadır. Bu beceriler, 2005 ders kitabında gerçek olaylar, durumlar üzerinden, gazete haberlerinden yararlanılarak; 2018'de ise; daha çok kurgusal metinler aracılığıyla öğrencilere kazandırılmaya çalışılmıştır. Önal ve Kaya (2006) çalışmasında, 4. ve 5. sınıf Sosyal Bilgiler ders kitaplarını değerlendirmiş, 2005 programına göre hazırlanan ders kitaplarındaki 
metinlerin, kullanılan resimlerin çocukların her gün karşılaşabilecekleri türden, günlük yaşamdan alınan, gerçekçi nitelikte resimler olduğu ve gazete haberlerine sıklıkla yer verildiği sonucuna ulaşılmıştır. Deveci (2005) çalışmasında, Sosyal Bilgiler dersinde öğrencilerin düşünme ve karar verme becerilerinin gelişmesi için güncel olaylarla ilgilenmelerinin gerekli olduğunu, güncel olayların öğretiminde ise; gazetelerin önemli bir araç olarak kullanılması gerektiği sonuçlarına ulaşmıştır. Sosyal Bilgiler dersinde kurmaca metinler yerine gazete kullanımı gibi günlük hayatla doğrudan bağ kurulabilecek metinlerin, araçların kullanılması, bu araçların doğru kullanımı konusundaysa öğretmenlerin bilinçlendirilmesi gerektiği düşünülmektedir.

\section{Ders Kitabından Örnekler}

\section{Empati Becerisi}

2005 ders kitabında empati becerisine dönük olarak sıklıkla kısa bilgilendirici metinler kullanıldığı görülmektedir. Bu metinlerden birinde geçen örnek ifade aşağıda verilmiştir:

“...Çocuklarına karşı çok merhametli olmasına rağmen bazen yaramazlıklarımızdan dolayı bize kızdığı da olur. Onu anlayabiliyorum."(sf. 27)

Empati becerisi, metinde bir çocuğun kendisini ailesinin yerine koyarak, onları anlayabilmesi şeklinde ifade edilmiştir.

2018 ders kitabında empati becerisine yönelik yer alan gazete haberindeki ifade de ise;

"Acil hastalar için aranması beklenen 112 Acil Komuta Merkezine dakikada onlarca gereksiz arama gelmesi sağlık operatörlerini zor durumda bırakıyor.. Siz yerlerinde olsaydınız?"(sf. 117)

Empati becerisi 2018 ders kitabında, farklı metin türleri ile öğrencilere kazandırılmaya çalışılmıştır. Gerçek hayat durumlarına yer verilmiş ve sağlık personellerinin yaşadığı zorluklar düşünülerek onlarla empati kurulmuştur.

\section{Mekânı Algılama Becerisi}

2005 ders kitabında, bilgilendirici metinler aracılığıyla mekânı algılama becerisi verilmeye çalışılmıştır. "Yönlerini Bildiler, Yollarını Buldular" başlıklı metinde ormanda yönlerini kaybeden çocukların doğadan yararlanarak yönlerini nasıl buldukları ifade edilmiş, bu yolla mekânı algılama becerisinin kazandırılması hedeflenmiştir (sf.68). 2018 ders kitabında ise; Hacivat Karagöz tiyatro metni ile bu beceri kazandırılmaya çalışılmıştır. "Karagöz Evini Arıyor" başlıklı metinde Karagöz'ün yönünü bulmaya çalışması ve bu sırada Hacivat’ın sözlerini yanlış anlaması ele alınmaktadır. Bu sayede çocukların eğlenerek öğrenebilmesinin ve öğrenmenin kalıcı olabilmesinin amaçlandığı düşünülmektedir (sf. 62). Mekânı algılama becerisi, 2005 ders kitabında bilgilendirici metinler aracılığıyla öğrencilere kazandırıımaya çalışılmış; 2018 ders kitabında ise, eğlenceli tiyatro metinleri ile bu becerinin kazandırılması hedeflenmiştir. Baloğlu-Uğurlu ve Aladağ (2015) tarafından yapılan, “Mekânsal Düşünmenin Türkiye'de Sosyal Bilgiler Öğretim Programındaki Yeri ve Öğretmenlerin Bu Beceri Hakkındaki Görüşleri” araştırmasında, öğretmenlerin öğrencilerin yaşadıkları mekânı tanımalarını ve o mekânla etkileşim içinde bulunmalarının gerektiği ifade edilmektedir. Araştırma sonucuna göre, öğretmenlerin bu becerinin kazandırılması için sıklıkla teknolojiden yararlandıkları ve literatürde de bu becerinin animasyonlar, dijital haritalar ile öğrencilere kazandırımasının, öğrenciler üzerinde olumlu yönde etkili olduğu sonuçlarına ulaşılmıştır.

\section{Zaman ve Kronolojiyi Algılama ile Değişim ve Sürekliliği Algılama Becerileri}

Zaman ve Kronolojiyi Algılama ile Değişim ve Sürekliliği Algılama becerileri her iki ders kitabında da üzerinde sıklıkla durulan beceriler olmuştur. 2005 programında bu becerilerin kazandırılması sıklıkla kavram karikatürleriyle, öğrencileri düşündürmeye ve eğlenmeye yöneltici şekilde, 2018 ders kitabında ise; sıklıkla geçmiş günümüz bağı kurup önemli icatları yapan kişilerin biyografilerinden yararlanılması şeklinde olmuştur.

\section{Kanit Kullanma Becerisi}

2018 ders kitabında üzerinde durulan beceridir. Bilgilendirici uzun metinler aracılığıyla ele alınmıştır. Metinler içeriğinde, kimlik belgelerinin geçmişten günümüze tanıtımı, parmak izinin önemi ve önemli tarihi olayların kronolojik sıralamasını kaynağa dayandırma yer almaktadır.

\section{Sosyal Katılım Becerisi}

Her iki ders kitabında da çeşitli metin türleri yoluyla ele alınan bu beceri, 2005 ders kitabında gerçek olaylar, durumlar üzerinden (gazete haberleri, mektup, dilekçe), 2018 ders kitabında ise daha çok; kurgusal metinler aracılığıyla öğrencilere kazandırılmaya çalışılmıştır.

\section{Görsellerde Derse Özgü Becerilerin Ele Alınışı}

2005 ve 2018 Sosyal Bilgiler ders kitapları incelendiğinde, görsellerde değişim ve sürekliliği algılama, zaman ve kronolojiyi algılama, mekânı algılama ve sosyal katılım becerilerinin ele alındığı görülmektedir. 2005 ders kitabında bu beceriler için kullanılan görsellerde kavram karikatürlerinden sıklıkla yararlanıldı̆̆ı, 2018 ders kitabında kavram karikatürlerinin hiç yer almadığı ve 2005 ders kitabında daha çok görsel, daha az yazı kullanılıp bu durumun 2018 ders kitabında tam tersi olduğu tespit edilmiştir. 2005 ders kitabındaki görseller, 2018 ile karşılaştırıldığında daha gerçekçi nitelikte olduğu söylenebilir. 
a. Değişim ve Sürekliliği Algılama ile Zaman ve Kronolojiyi Algılama Becerilerine Yönelik Ders Kitaplarındaki Görseller
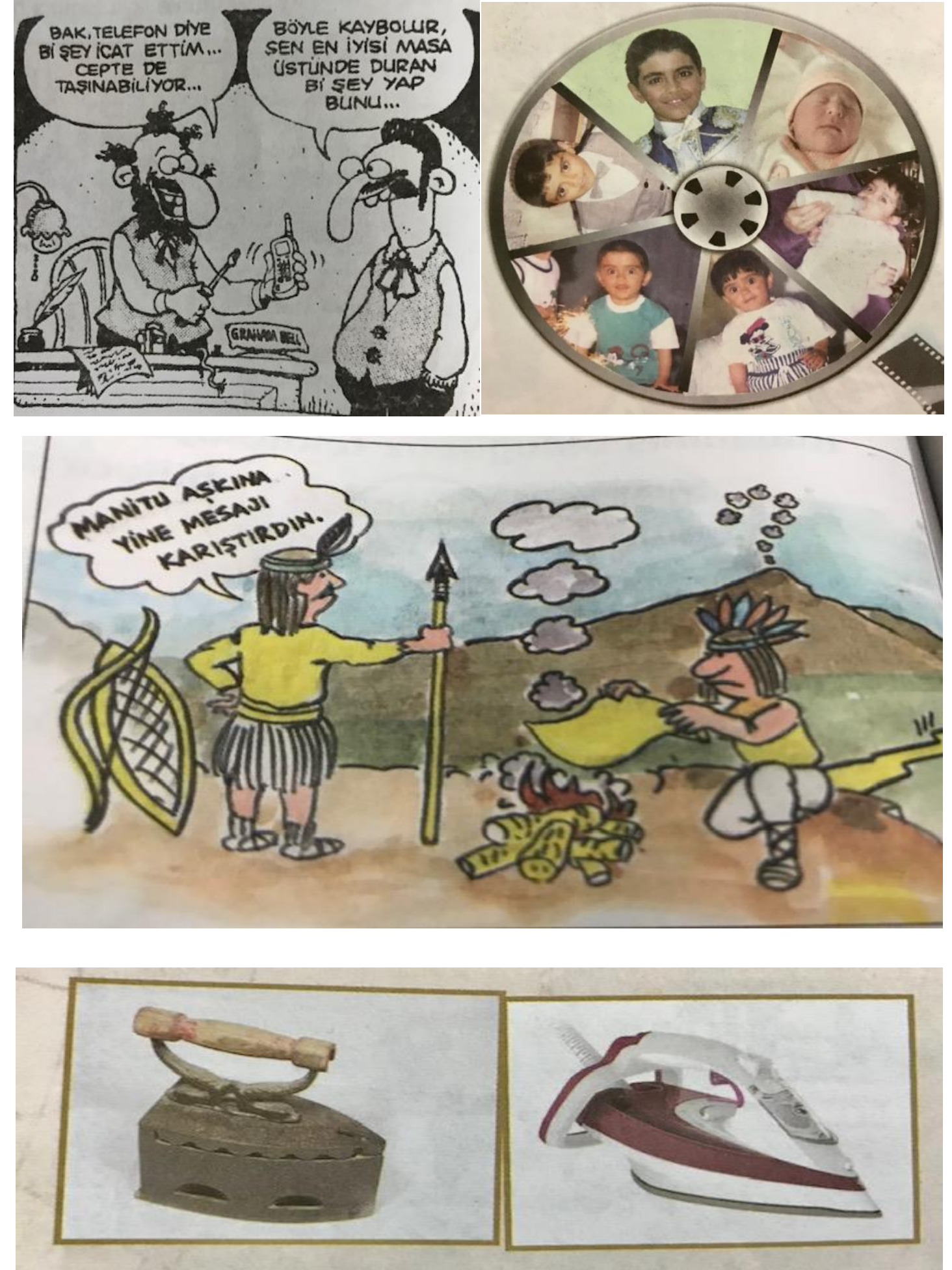

Şekil 1. 2005 ders kitabında yer alan değişim ve sürekliliği algılama ile zaman ve kronolojiyi algılama becerilerine yönelik örnek görseller

2005 ders kitabında sıklıkla kavram karikatürlerine yer verildiği görülmektedir. Karikatürler dışında kullanılan görseller ise; genellikle gerçekçi nitelikte; yani günlük yaşama uygun, yaşamda karşılaşılan resimlerdir. 

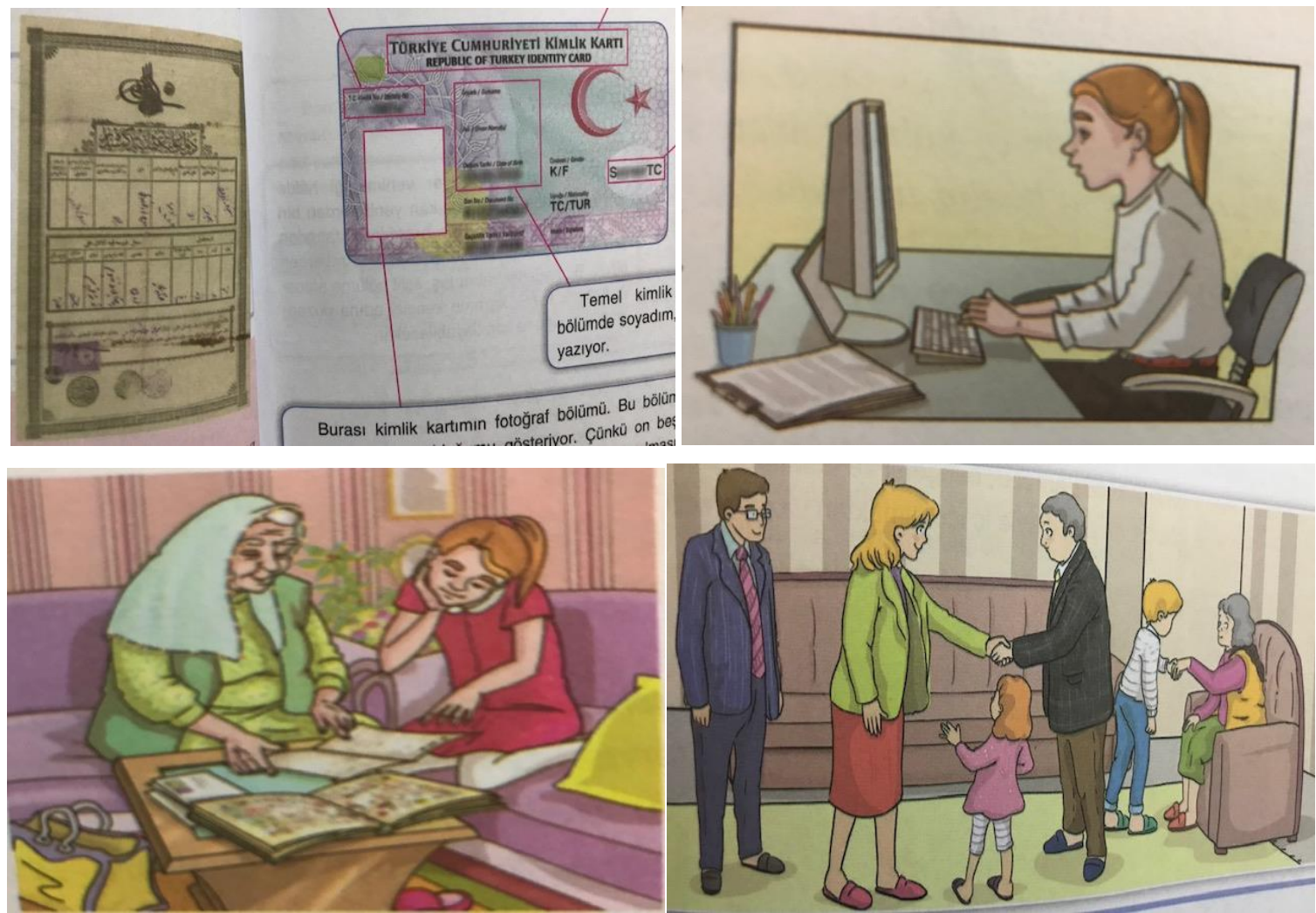

Şekil 2. 2018 ders kitabında yer alan değişim ve sürekliliği algılama ile zaman ve kronolojiyi algılama becerilerine yönelik örnek görseller

2018 ders kitabındaki görseller daha çok, metne göre çizilmiş gerçek olmayan resimlerdir. Kavram karikatürlerine yer verilmediği görülmektedir. Metne göre çizilmiş resimlerde, konuya göre tasarlanan çizimler bulunmaktadır. Kişilerin yüzleri veya çevredeki objelerin, orijinalinden farklı, daha yapay gösterildiği görülmektedir. 2018 ders kitabında, bu durumun ağır bastığı düşünülmektedir.

\section{b. Mekânı Algılama Becerisine Yönelik Ders Kitaplarındaki Görseller}
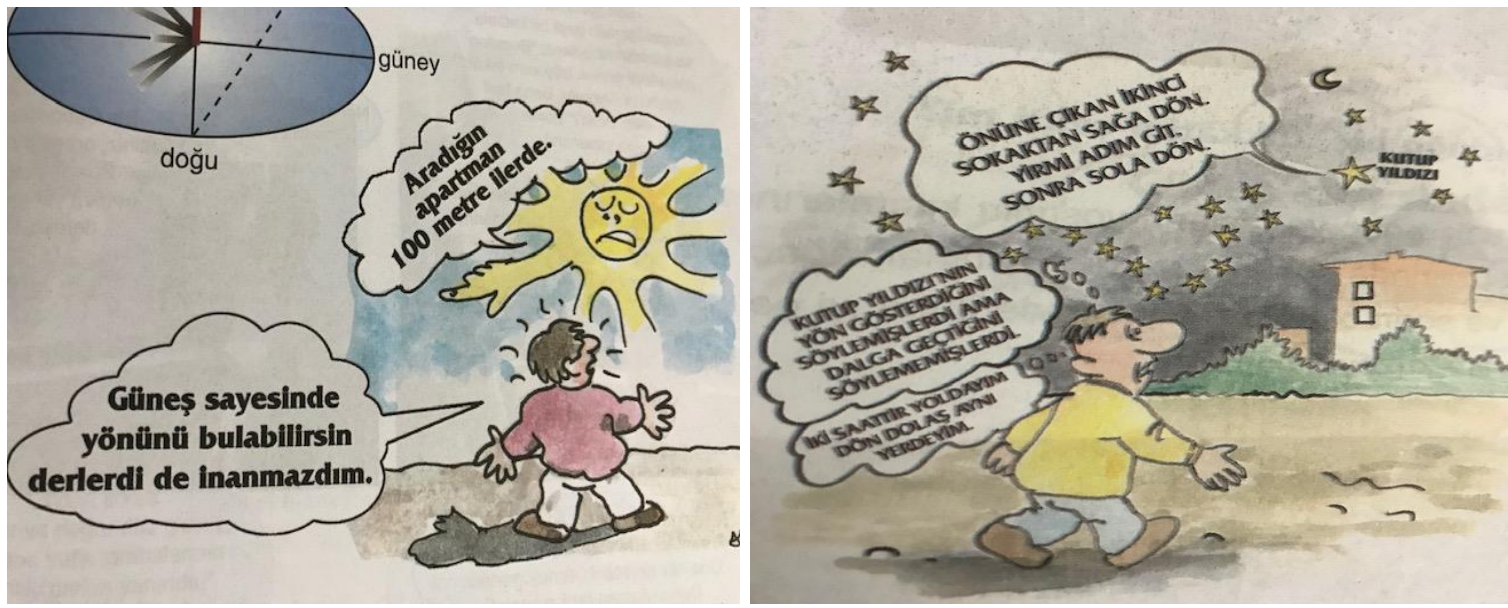

Şekil 3. 2005 ders kitabında yer alan mekanı algılama becerisine yönelik örnek görseller

2005 ders kitabında mekanı algılama becerisine yönelik olarak, kavram karikatürü niteliğindeki çizimlerden yararlanıldığı görülmektedir. 

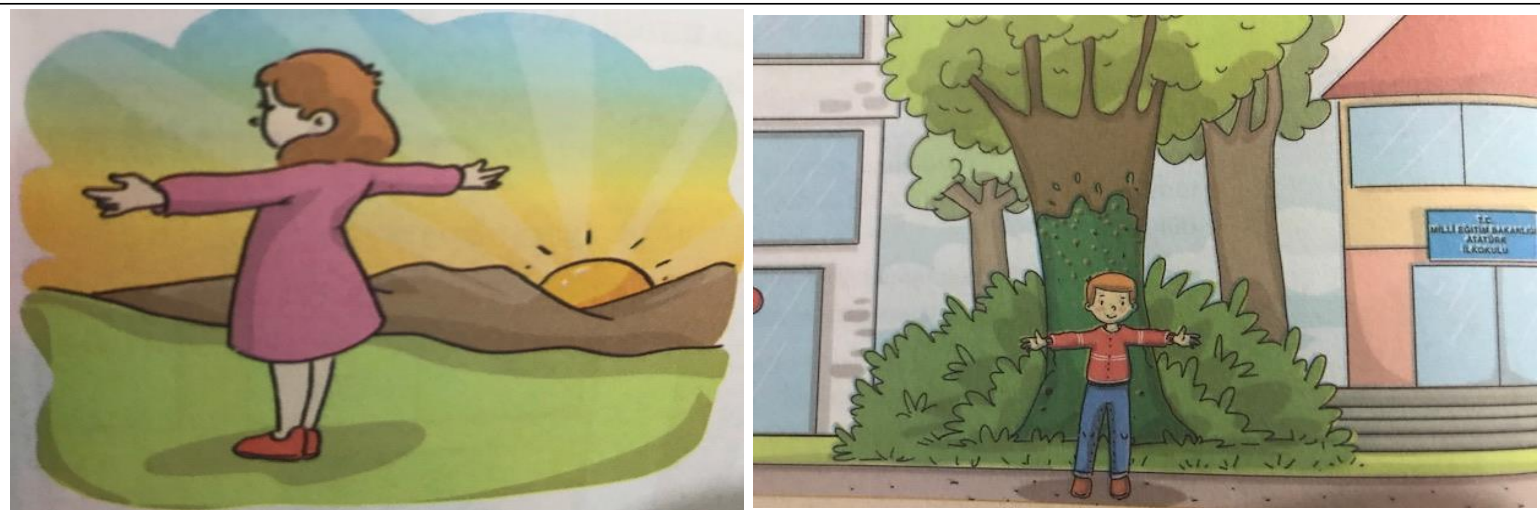

Şekil 4. 2018 ders kitabında yer alan mekanı algılama becerisine yönelik örnek görseller

2018 ders kitabında yer alan görsellerin metne göre çizilen resimler olduğu dikkat çekmektedir. 2005'te kullanılan, karikatür niteliğindeki çizimlerin, çocukların resme baktıklarında ne anlatılmak istendiğini daha iyi anlamalarını sağlayacağı, kazandırılmak istenen becerilerin somutlaştırılmasına yarayacağı ve sınıf içi tartışma ortamı yaratarak öğrencilerin sürece aktif katılımlarını arttıracağı düşünülmektedir.

\section{c. Sosyal Katılım Becerisine Yönelik Ders Kitaplarındaki Görseller}
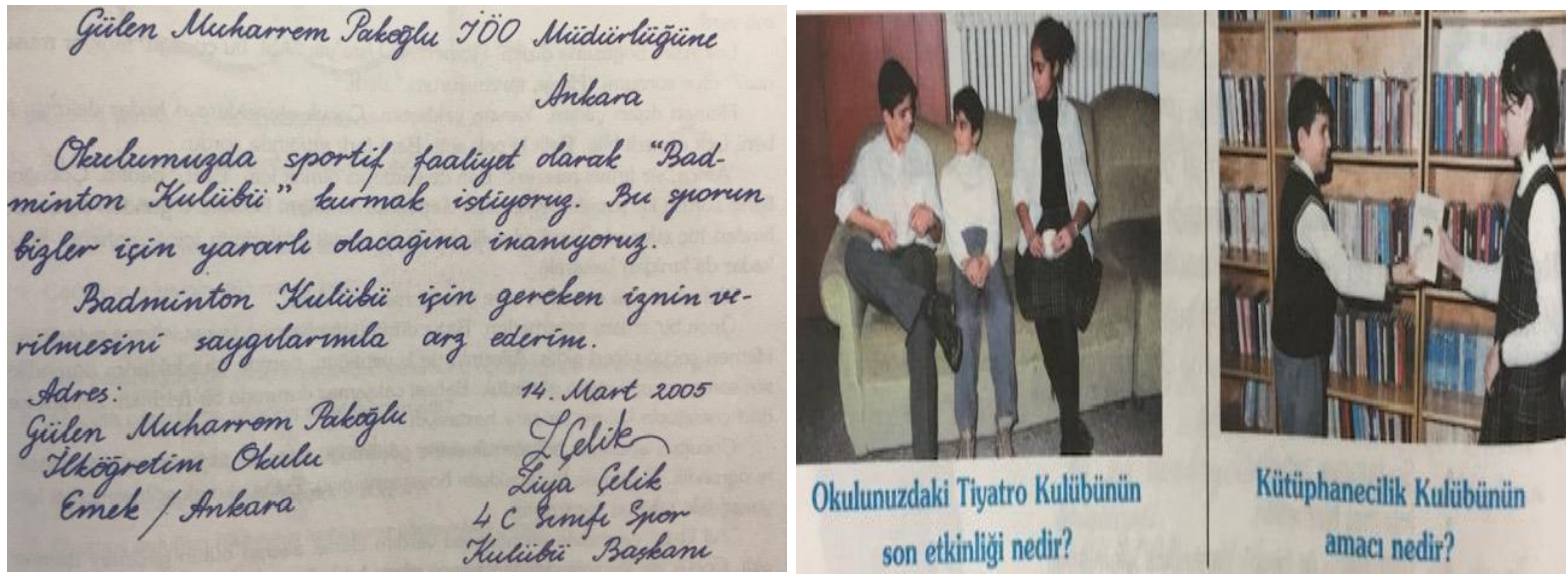

Şekil 5. 2005 ders kitabında yer alan sosyal katılım becerisine yönelik örnek görseller

2005'te sosyal katılım becerisine yönelik olarak kullanılan görsellerin, dilekçe örneği ve gazate haberlerinden örnekler gibi gerçek hayat durumlarıyla ilgili olduğu görülmektedir.
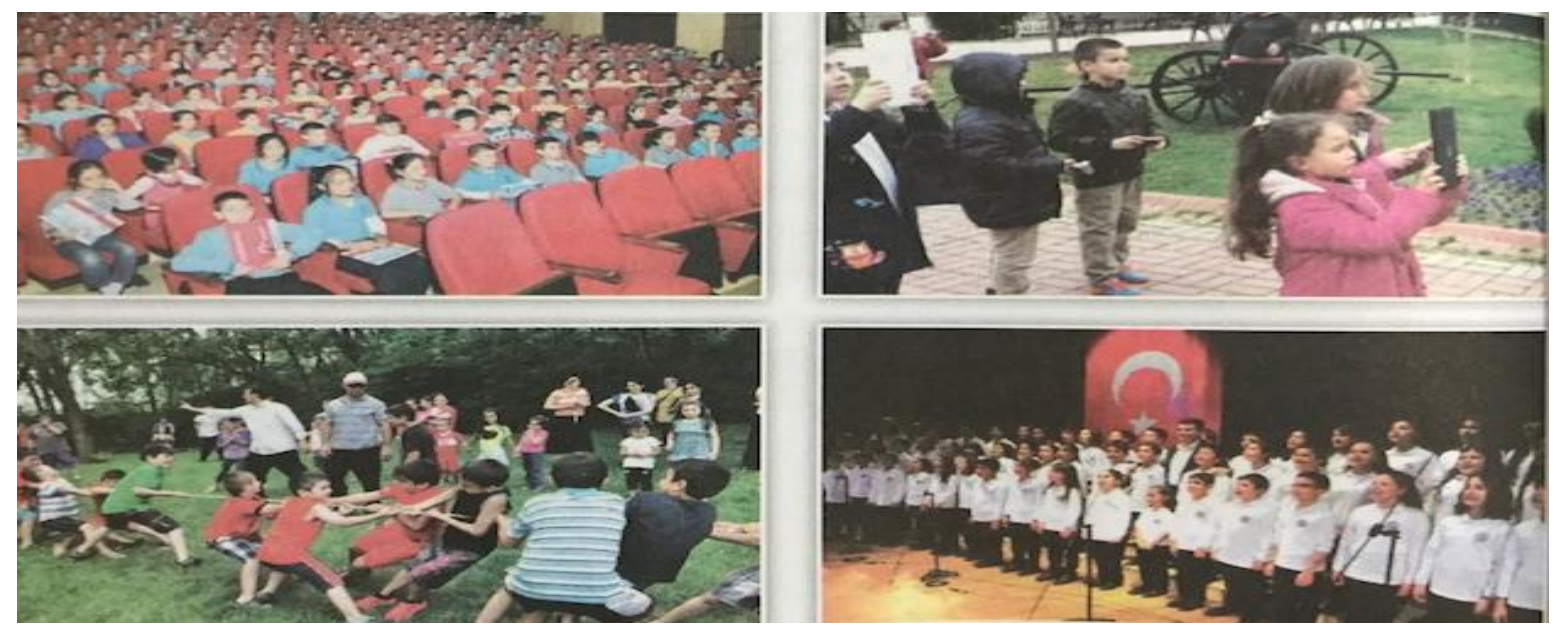

Şekil 6. 2018 ders kitabında yer alan sosyal katılım becerisine yönelik örnek görseller

2018 ders kitabındaki görsellerin metne göre hazırlanmış olan, sosyal ve kültürel etkinliklerden örnek resimler olduğu görülmektedir. Ders kitaplarında yer alan görseller, "beceri eğitimi” açısından incelendiğinde; 2005 ders kitabında derse özgü beceriler için kullanılan görsellerde kavram karikatürlerinden sıklıkla yararlanıldığı, 2018 ders kitabında kavram karikatürlerinin hiç 
yer almadığı ve 2005 ders kitabında daha çok görsel, daha az yazı kullanılıp bu durumun 2018 ders kitabında tam tersi olduğu tespit edilmiştir. 2005 ders kitabındaki görseller, 2018 ile karşılaştırıldığında daha gerçekçi niteliktedir.

Şahin (2014), araştırmasında; Sosyal Bilgiler ders kitaplarında görsel tasarım ilkelerinin etkili kullanılmadığı; resim, fotoğraf gibi öğelerin sıklıkla yer alıp kavram haritası, kavram karikatürleri, şema, bulmaca, grafik gibi unsurlara yer verilmediği sonuçlarına ulaşılmıştır. Tokcan ve Alkan (2013), Sosyal Bilgiler öğretiminde kavram karikatürlerinin öğrenci başarısına etkisini incelemiş ve kavram karikatürleri ile desteklenerek yapılan öğretimin geleneksel veya programa dayalı öğretime göre daha etkili olduğu sonuçlarına ulaşmıştır. Literatür bu durumu destekler niteliktedir (Akbaş ve Toros, 2016; Sidekli, Er, Yavaşer ve Aydın, 2014; Topcubaşı ve Polat, 2014).

\section{Derse Özgü Becerilerin Ölçme ve Değerlendirme Boyutunda Ele Alınışı}

Bu bölümde, Sosyal Bilgiler dersine özgü becerilere yönelik olarak ders kitaplarında yer alan sorular incelenmiştir. Tablo 4'te, 2005 ve 2018 Sosyal Bilgiler ders kitaplarında yer alan değerlendirme sorularında, derse özgü hangi becerileri ölçmeye ağırlık verildiği ve hazırlanan soruların hangi türde oldukları yer almaktadır. Beceriler, öğrenme alanlarına göre ayrı ayrı ele alınmıştır.

Tablo 4. 2005 ve 2018 sosyal bilgiler ders kitaplarında yer alan öğrenme alanlarındaki derse özgü becerilerin değerlendirme sorularına göre ele alınışına yönelik bulgular

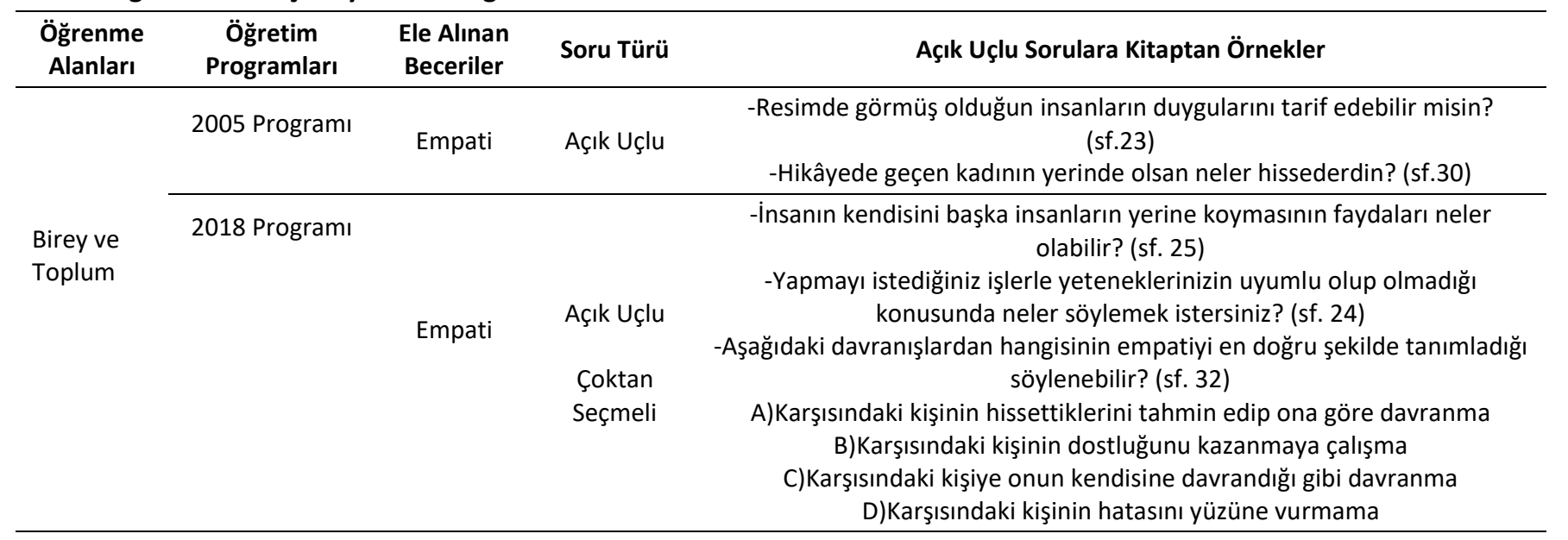

\begin{tabular}{|c|c|c|c|c|}
\hline \multirow{2}{*}{$\begin{array}{l}\text { Kültür ve } \\
\text { Miras }\end{array}$} & 2005 Programı & $\begin{array}{l}\text { b)Değişim } \\
\text { ve } \\
\text { Sürekliliği } \\
\text { Algılama }\end{array}$ & Açık Uçlu & $\begin{array}{l}\text { a)-...bu konuşmayı dinlerken neler hissetmiş olabilir? (sf. 39) } \\
\text { a)Şuana kadar gördüğün düğünlerde neler hissettin? (sf. 45) } \\
\text { b)Kültürel özelliklerin değişimini mesleklerden örnekler vererek } \\
\text { açıklayabilir misin? (sf. 65) }\end{array}$ \\
\hline & 2018 Programı & $\begin{array}{l}\text { a)Zaman } \\
\text { ve } \\
\text { Kronolojiyi } \\
\text { Algılama } \\
\text { b)Kanıt } \\
\text { Kullanma }\end{array}$ & Açık Uçlu & $\begin{array}{l}\text { a)Çevrenizde gördüğünüz ve etnografya müzelerinde sergilenmesi } \\
\text { gerektiğini düşündüğünüz nesnelere hangi örnekleri verebilirsiniz? (sf. 40) } \\
\text { b)Aile tarihinizi yazarken evinizde bulunan yazılı ve görsel belgeler ile } \\
\text { eşyalardan hangilerinin size yardımcı olacağını söyleyebilirsiniz? Neden? } \\
\text { (sf. } 34)\end{array}$ \\
\hline \multirow[b]{2}{*}{$\begin{array}{l}\text { İnsanlar, } \\
\text { Yerler ve } \\
\text { Çevreler }\end{array}$} & 2005 Programı & $\begin{array}{l}\text { Mekânı } \\
\text { Algılama }\end{array}$ & Açık Uçlu & $\begin{array}{c}\text {-Karınca yuvalarına bakarak yön tespit edebilir misin? Doğadan } \\
\text { yararlanarak yönünü bulabilir misin? (sf. 70) } \\
\text {-Bu tarifle postaneyi bulabilir miydin? (sf. 72) }\end{array}$ \\
\hline & 2018 Programı & $\begin{array}{l}\text { a)Mekânı } \\
\text { Algılama } \\
\text { b)Konum } \\
\text { Analizi }\end{array}$ & $\begin{array}{l}\text { Açık Uçlu } \\
\text { Boşluk } \\
\text { Doldurma }\end{array}$ & $\begin{array}{l}\text { a)Karagöz’e yönünü bulma konusunda yardım etmek isteseydiniz ona } \\
\text { hangi önerilerde bulunurdunuz? (sf. 62) } \\
\text { b)Güneş...doğup...batar. (sf. 90) } \\
\text { b)Haritalar olmasaydı neleri yapmakta zorlanırdık? Neden? (sf. 77) }\end{array}$ \\
\hline \multirow{2}{*}{$\begin{array}{l}\text { Üretim, } \\
\text { Tüketim } \\
\text { ve Dağıtım }\end{array}$} & 2005 Programı & - & - & - \\
\hline & 2018 Programı & $\begin{array}{l}\text { Mekânı } \\
\text { algılama }\end{array}$ & Açık Uçlu & $\begin{array}{l}\text {-İzmit ve çevresinin ekonomik faaliyetleri ile yaşadığınız yerin ekonomik } \\
\text { faaliyetleri arasındaki benzerlikler ve farklılıklar nelerdir? (sf. 130) }\end{array}$ \\
\hline $\begin{array}{l}\text { Bilim } \\
\text { Teknoloji } \\
\text { ve Toplum }\end{array}$ & 2005 Programı & $\begin{array}{l}\text { Değişim ve } \\
\text { Sürekliliği } \\
\text { Algılama }\end{array}$ & Açık Uçlu & $\begin{array}{l}\text {-Zaman belirleme araçlarından saatin geçmişten günümüze gelişimi nasıl } \\
\text { olmuştur? (sf. 143) }\end{array}$ \\
\hline
\end{tabular}




\begin{tabular}{lcccc}
\hline $\begin{array}{c}\text { Öğrenme } \\
\text { Alanları }\end{array}$ & $\begin{array}{c}\text { Öğretim } \\
\text { Programları }\end{array}$ & $\begin{array}{c}\text { Ele Alınan } \\
\text { Beceriler }\end{array}$ & Soru Türü & Açık Uçlu Sorulara Kitaptan Örnekler \\
\hline & 2018 Programı & $\begin{array}{c}\text { Değişim ve } \\
\text { Sürekliliği } \\
\text { Algılama }\end{array}$ & Açık Uçlu & $\begin{array}{c}\text {-Seyahatler gibi teknolojinin gelişimiyle birlikte değişime uğrayan insan } \\
\text { faaliyetlerine başka hangi örnekleri verebilirsiniz? (sf. 102) } \\
\text {-ilk halinden günümüze kadar en köklü değişime uğramış olan teknolojik } \\
\text { ürün hangisidir? Neden? (sf. 120) }\end{array}$ \\
\hline \multirow{2}{*}{$\begin{array}{l}\text { Küresel } \\
\text { Bağlantılar }\end{array}$} & 2005 Programı & - & - & - \\
\cline { 2 - 5 } & 2018 Programı & $\begin{array}{c}\text { Eleştirel } \\
\text { Düşünme }\end{array}$ & Açık Uçlu & -Sizce insanlar farklı kültürlere neden saygı göstermelidir? (sf. 195) \\
\hline
\end{tabular}

Tablo 4'de Üretim, Tüketim ve Dağıtım ile Küresel Bağlantılar öğrenme alanlarına yönelik olarak, 2005 ders kitabında becerileri kazandırmaya dönük sorulara yer verilmediği görülmektedir. Bu durumun, beceri eğitimine 2018 programında daha fazla önem verildiğini destekler niteliktedir. Oysaki bu öğrenme alanlarına dönük becerilerin kazandırıması için, sürecin değerlendirme sorularıyla desteklenmesi gerektiği düşünülmektedir. Değerlendirme soruları, performans görevleri şeklinde olursa, öğrencilerin daha etkin olacağı ve bu becerileri içselleştireceği düşünülmektedir.

Tablo 5. 2005 ve 2018 sosyal bilgiler öğretim programlarında ortak olmayan öğrenme alanlarındaki derse özgü becerilerin değerlendirme sorularına göre ele alınışı

\begin{tabular}{|c|c|c|c|c|}
\hline $\begin{array}{c}\text { Öğretim } \\
\text { Programları }\end{array}$ & Öğrenme Alanları & $\begin{array}{c}\text { Ele Alınan } \\
\text { Beceriler }\end{array}$ & Soru Türü & Açık Uçlu Sorulara Kitaptan Örnekler \\
\hline 2005 Programı & $\begin{array}{l}\text { Gruplar, Kurumlar ve } \\
\text { Sosyal Örgütler }\end{array}$ & Sosyal Katılım & Açık Uçlu & $\begin{array}{c}\text {-Katıldığın ya da televizyondan izlediğin } \\
\text { bir nikâh törenini anlatabilir misin? (sf } \\
\text { 146) } \\
\text {-Okulunuzda başlatabileceğiniz bir } \\
\text { sosyal etkinlik öneriniz. } \\
\text { (sf. 159) }\end{array}$ \\
\hline 2005 Programı & $\begin{array}{l}\text { Güç, Yönetim ve } \\
\text { Toplum }\end{array}$ & Sosyal Katılım & Açık Uçlu & $\begin{array}{l}\text {-...böyle bir yardım grubu kurmaya ne } \\
\text { dersin? (sf. 179) } \\
\text {-... böyle bir seçimde aday olmak ister } \\
\text { misin? (sf. 181) }\end{array}$ \\
\hline 2018 Programı & Etkin Vatandaşlık & Sosyal Katılım & Açık Uçlu & $\begin{array}{c}\text {-Çocukların barınma, beslenme ve } \\
\text { sağlık hizmetlerinden gerektiği gibi } \\
\text { faydalanmaları için neler yapılmalıdır? } \\
\text { (sf. 155) } \\
\text {-Okulunuzda hangi eğitsel ve sosyal } \\
\text { etkinlikler yapılıyor? (sf. 163) } \\
\text {-Okulunuzda Okuma Çemberi } \\
\text { Topluluğu kurarak faaliyette bulunmak } \\
\text { ister misiniz? (sf. 166) }\end{array}$ \\
\hline
\end{tabular}

Tablo 4 ve Tablo 5 incelendiğinde, daha az becerinin sorular yoluyla kazandırılmaya çalışıldığı görülmektedir. 2018 ders kitabı, 2005'e göre daha fazla becerinin kazandırılmasını hedeflemektedir. 2005'te genellikle açık uçlu sorulardan yararlanılırken, 2018 ders kitabında empati ve mekanı algılama becerileriyle ilgili, çoktan seçmeli ve boşluk doldurma sorularının da bulunduğu tespit edilmiştir. 2005 ders kitabında "Küresel Bağlantılar" öğrenme alanında kitapta yer alan sorularda herhangi bir becerinin kazandırılmaya çalışıldığı görülmemektedir. Sorular incelendiğinde ise; genel olarak 2018 ders kitabında yer alan soruların daha kapsamlı ve daha üst düzey olduğu görülmektedir. 2005 programındaki “Gruplar, Kurumlar ve Sosyal Örgütler" ve "Güç, Yönetim ve Toplum" öğrenme alanları ile 2018 programındaki 'Etkin Vatandaşlık' öğrenme alanında yer alan ders kitaplarındaki sorular incelendiğinde; ele alınan derse özgü becerinin "sosyal katılım” becerisi olduğu görülmektedir. ders kitaplarında sıklıkla açık uçlu sorulardan yararlanılmış olup soruların niteliği incelendiğinde; 2005'te hazırlanan soruların daha uygulamaya dönük olduğu göze çarpmaktadır. Ders kitaplarının, ölçme ve değerlendirme boyutunda; derse özgü becerilere yönelik hazırlanan soruların daha çok açık uçlu nitelikte olduğu, 2018'de daha çok becerinin sorular aracılığıyla kazandırılmaya çalışıldığı ancak kullanılan metinlere ve yararlanılan görsellere göre, ölçme ve değerlendirme bölümünde derse özgü becerilerin kazandırılmasının yeterli düzeyde olmadığı (Gülersoy, 2013) sonuçlarına ulaşılmıştır. Soruların niteliği incelendiğinde; 2005'te hazırlanan soruların daha üst düzeyde olduğu, öğrencilerin çıkarım yapmalarına yönelik olduğu görülmektedir. Literatür bu sonucu desteklemektedir (Önal ve Kaya, 2006). 


\section{SONUÇ VE ÖNERILER}

2005 ve 2018 Sosyal Bilgiler ders kitaplarındaki derse özgü becerilerin öğretiminin karşılaştırılmasını amaçlayan bu araştırmada; ders kitaplarında yer alan metinlerde, görsellerde ve kitapların ölçme ve değerlendirme bölümlerinde derse özgü becerilerin nasıl ele alındığı incelenmiştir. Araştırmanın birinci alt problemine göre; 2018 ders kitabında daha fazla becerinin, daha fazla metin türüyle öğrencilere kazandırılmaya çalışıldığı; 2005 ders kitabının metin türü açısından, 2018'e göre daha sınırlı olduğu görülmektedir. Metin türleri incelendiğinde; 2018 ders kitabındaki bilgilendirici metinlerin, 2005 ders kitabına göre daha uzun olduğu ve 2018 ders kitaplarındaki metin türlerinin beceri kazandırılma açısından 2005’e göre daha fazla çeşitlilik gösterdiği görülmektedir.

Araştırmanın ikinci alt problemine yönelik bulgular incelendiğinde, ders kitaplarındaki görsellerde sadece değişim ve sürekliliği algılama, zaman ve kronolojiyi algılama, mekânı algılama ve sosyal katılım becerilerinin ele alındığı görülmektedir. 2005 ders kitabında bu beceriler için kullanılan görsellerde kavram karikatürlerinden sıklıkla yararlanıldığı, 2018 ders kitabında kavram karikatürlerinin hiç yer almadığı ve 2005 ders kitabında daha çok görsel, daha az yazı kullanılıp bu durumun 2018 ders kitabında tam tersi olduğu tespit edilmiştir. 2005 ders kitabındaki görseller, 2018 ile karşılaştırıldığında daha gerçekçi niteliktedir.

Araştırmanın üçüncü alt probleminde ise; ölçme ve değerlendirme boyutunda, 2018 ders kitabında, 2005’e göre daha fazla becerinin kazandırılması hedeflendiği görülmektedir. 2005'te genellikle açık uçlu sorulardan yararlanılırken, 2018'de çoktan seçmeli ve boşluk doldurma sorularından da yararlanıldığı tespit edilmiştir. Sorular incelendiğinde ise; genel olarak 2018 ders kitabında yer alan soruların daha kapsamlı ve daha üst düzey olduğu görülmektedir.

Araştırmanın sonucunda, 2005 öğretim programına göre hazırlanmış ders kitabında öğrencilere daha az becerinin kazandırılmaya çalışımasının, beceri eğitiminin niteliği açısından daha faydalı olacağı düşünülmektedir. Nicelik bakımından fazla becerinin kazandırıma amacının, teoride faydalı görülse de öğrencilerin bu becerileri içselleştirmesi açısından zor olacağına inanılmaktadır. 2018'de metin türü açısından çeşitliliğin fazla olmasının ise, öğrenci dikkati ve ilgisi göz önüne alındığında, yararlı olabileceği düşünülmektedir. Edinim açısından yetersiz olup sayıca çok becerinin kazandırılmaya çalışılması yerine; bu durumun tersinin hedeflenmesi önerilmektedir.

Ders kitaplarındaki görseller incelendiğinde, görsellerin eğlenceli, öğrenciye dönük olması, kavram karikatürleri gibi öğrencilerin dikkatini çekecek şekilde tasarlanması önerilmektedir. Fazla yazı, az resim olduğunda öğrenciler metinden sıkılabilir. Özellikle ilkokul düzeyinde uygun görsellerden yararlanılmasının gerekli olduğuna inanılmaktadır. Görsellerin kurgusal olmak yerine daha gerçekçi, gerçek hayat durumlarından örnekler şeklinde verilmesinin "öğrenciye görelilik" açısından ne derece doğru olacağı üzerine çalışmaların yapılması önerilebilir. Ders kitaplarındaki ölçme ve değerlendirmeye yönelik olarak ise; öğrencilere kısa cevaplı $5 \mathrm{~N} 1 \mathrm{~K}$ soruları yöneltmek yerine, 21.yüzyıl’ın gereğine uygun şekilde; düşünen, araştıran, sorgulayan bireylerin yetişmesi açısından üst düzey düşünmeye yönlendirici, açık uçlu soruların kullanılmasının önemli olduğuna inanılmaktadır. Ders kitaplarının bu doğrultuda hazırlanarak, ölçme-değerlendirme boyutunda, nitelikli sorulara yer verilmesi önerilmektedir.

\section{KAYNAKÇA}

Akbaş, Y., \& Toros, S. (2016). Sosyal bilgiler öğretiminde interaktif kavram karikatürleri ve kavram haritaları kullanımının akademik başarıya etkisi. International Periodical for the Languages, Literature and History of Turkish or Turkic, 11(9), 53-68.

Aydemir, M., \& Adamaz, K. (2017). Sosyal bilgiler öğrenci çalışma kitaplarının sosyal bilgiler dersi öğretim programındaki beceriler açısından incelenmesi. International Journal of Field Education, 3(1), 106-119.

Baloğlu-Uğurlu, N., \& Aladağ, E. (2015). Mekânsal düşünmenin Türkiye'de sosyal bilgiler öğretim programındaki yeri ve öğretmenlerin bu beceri hakkındaki görüşleri. Marmara Coğrafya Dergisi, 35, 22-42.

Chuang, C.W., Hwang, G.J., \& Tsai, W.J. (2018). A peer tutoring-based concept mapping approach to improving students' learning achievements and attitudes for a social studies course. International Journal of Online Pedagogy and Course Design (IJOPCD), 8(1), 12.

Cüro, E., \& Gömleksiz, M. N. (2011). Sosyal bilgiler dersi öğretim programında yer alan değerlere ilişkin öğrenci tutumlarının değerlendirilmesi. Uluslararası insan Bilimleri Dergisi, 8(1), 95-134.

Çelikkaya, T. (2011). Sosyal bilgiler programında yer alan becerilerin kazandııılma düzeyi: öğretmen görüşleri. Kastamonu Eğitim Dergisi, 19(3), 969-990.

Çelikkaya, T., \& Kürümlüoğlu,, M. (2019). 4. ve 5. sınıf yeni sosyal bilgiler programında kazandırılması hedeflenen ortak becerilere ilişkin kazanımların içeriğe yansıması. Uluslararası Ders Kitapları ve Eğitim Materyalleri Dergisi, 2(2), 166-186.

Dawson, C. (2009). Introduction to research methods: a practical guide for anyone undertaking a research project. Oxford: How to Books Ltd.

Deveci, H. (2005). Sosyal bilgiler dersinde gazete kullanımı. Sakarya Üniversitesi Online Dergisi, 4(3), 159-166.

Gülersoy, A. E. (2013). İdeal ders kitabı arayışında sosyal bilgiler ders kitaplarının bazı özellikler açısından incelenmesi. International Journal of New Trends in Arts, Sports \& Science Education, 2(1), 8-26.

Hayırsever, F., \& Kısakürek, M. A. (2014). Sosyal bilgiler ders kitabının ilköğretim programında kazandırılması hedeflenen beceriler açııından değerlendirilmesi. Uluslararası Eğitim Programları ve Öğretim Çalışmaları Dergisi, 4(8), 23-42.

Karasu-Avcı, E., \& Faiz, M. (2018). 4. ve 5. sınıf sosyal bilgiler ders kitapları “etkin vatandaşık” öğrenme alanında yer alan becerilerin ve değerlerin incelenmesi. Uluslararası Sosyal Bilgilerde Yeni Yaklaşımlar Dergisi (IJONASS), 2(1), 1-21.

Kaymakcı, S. (2009). Yeni sosyal bilgiler programı neler getirdi?. Gazi Eğitim Fakültesi Dergisi Prof. Dr. Reşat Genç'e Armağan Özel Sayısı, 15301545.

| Kastamonu Eğitim Dergisi, 2020, Vol. 28, No. 6| 
Kaymakcı, S. (2013). Sosyal bilgiler ders kitaplarında sözlü ve yazılı edebî türlerin kullanım durumu. Dicle Üniversitesi Ziya Gökalp Eğitim Fakültesi Dergisi, 20(13), 230-255.

Kıroğlu, K. (2006). Öğretenler ve öğrenenler için ek açıklamalarla ilköğretim programları (1-5. sınıflar). Ankara: Pegem A Yayıncılık.

Kuş, Z., Merey, Z., \& Karatekin, K. (2013). Illköğretim 4. ve 5. sınıf sosyal bilgiler ders kitaplarında yer alan değerler. Değerler Eğitimi Dergisi, 11(25), 183-214.

Miles, M. B., \& Huberman, A. M. (1994). Qualitative data analysis: an expanded sourcebook. London: Sage Ltd.

Milli Eğitim Bakanlığı (2005). İlköğretim sosyal bilgiler dersi öğretim programı ve kılavuzu (4-5.sınıflar). Ankara: Talim ve Terbiye Kurulu Başkanlığı Devlet Kitapları Müdürlüğü Basımevi.

Milli Eğitim Bakanlığı (2018). İlköğretim sosyal bilgiler dersi öğretim programı ve kılavuzu (4-5. sınıflar). Ankara: Talim ve Terbiye Kurulu Başkanlığı Devlet Kitapları Müdürlüğü Basımevi.

Mutluer, C. (2013). Sosyal bilgiler programlarında yer alan beceriler hakkında sosyal bilgiler öğretmen görüşleri (İzmir menemen örneği). Turkish Studies, 8(7), 355-362.

Önal, H., \& Kaya N. (2006). Sosyal bilgiler ders kitaplarının (4 ve 5. sınıf) değerlendirilmesi. Balıkesir Üniversitesi Sosyal Bilimler Enstitüsü Dergisi. 9(16), 21-39.

Öztürk, M., \& Mutlu, N. (2017). Sosyal bilgiler ve tarih derslerinde beceri ve değerleri ne kadar öğretiyoruz?. Sakarya University Journal of Education, 7(3), 552-563.

Sidekli, S., Er, H., Yavaşer, R., \& Aydın, E. (2014). Sosyal bilgiler öğretiminde alternatif bir yöntem: karikatür. Uluslararası Türk Eğitim Bilimleri Dergisi, 2(2), 151-163.

Sözen, E., \& Ada, S. (2018). 2005 ve 2018 4. sınıf sosyal bilgiler dersi öğretim programlarının (sbdöp) karşılaştırılması. Anadolu Eğitim Liderliği ve Öğretim Dergisi, 6(1), 53-71.

Şahin, M. (2014). Sosyal bilgiler ders kitaplarının görsel tasarım ilkeleri açısından değerlendirilmesi. Çukurova Üniversitesi Sosyal Bilimler Enstitüsü Dergisi, 23(1), 31-46.

Tay, B. (2017). 2005 sosyal bilgiler dersi öğretim programı ile 2017 sosyal bilgiler dersi taslak öğretim programının karşılaştırması. International Journal of Eurasia Social Sciences, 8(27), 461-487.

Tokcan, H., \& Alkan, G. (2013). Sosyal bilgiler öğretiminde kavram karikatürlerinin öğrenci başarısına etkisi. Ahi Evran Üniversitesi Kırşehir Eğitim Fakültesi Dergisi, 14(2). 1-19.

Topcubaşı, T., \& Polat, S. (2014). Sosyal bilgiler öğretiminde kavram karikatürlerinin öğrenci başarısına etkisi. International Journal of New Trends in Arts, Sports \& Science Education (ljtase), 3(2), 48-61.

Yalçın, A., \& Akhan, N. E. (2019). Cumhuriyetten günümüze sosyal bilgiler programlarının sosyal bilgiler öğretim yaklaşımlarına göre incelenmesi. Kuramsal Eğitimbilim Dergisi [Journal of Theoretical Educational Science], 12(3), 842-873.

Yıldırım, A., \& Şimşek, H. (2013). Sosyal bilimlerde nitel araştırma yöntemleri (9. Baskı). Ankara: Seçkin Yayıncılık. 